\title{
A Short Review on the Intranasal Delivery of Diazepam for Treating Acute Repetitive Seizures
}

\author{
Sai H. S. Boddu $1,2, * \mathbb{D}$ and Sneha Kumari ${ }^{3}$ \\ 1 Department of Pharmaceutical Sciences, College of Pharmacy and Health Sciences, Ajman University, \\ Ajman P.O. Box 346, UAE \\ 2 Center of Medical and Bio-allied Health Sciences Research, Ajman University, Ajman P.O. Box 346, UAE \\ 3 Department of Pharmacy Practice, The University of Toledo, Health Science Campus, 3000 Arlington Ave, \\ Toledo, OH 43614, USA; sneha.kumari@utoledo.edu \\ * Correspondence: s.boddu@ajman.ac.ae
}

Received: 9 November 2020; Accepted: 26 November 2020; Published: 30 November 2020

check for updates

\begin{abstract}
Benzodiazepines such as diazepam, lorazepam and midazolam remained the mainstay of treatment for acute repetitive seizures (ARS). The immediate care for ARS should often begin at home by a caregiver. This prevents the progression of ARS to prolonged seizures or status epilepticus. For a long time and despite social objections rectal diazepam gel remained only FDA-approved rescue medication. Intranasal administration of benzodiazepines is considered attractive and safe compared with rectal, buccal and sublingual routes. Intranasal delivery offers numerous advantages such as large absorptive surface area, bypass the first-pass metabolism and good patient acceptance as it is needle free and painless. Recent clinical studies have demonstrated that diazepam nasal spray (NRL-1; Valtoco ${ }^{\circledR}$, Neurelis Inc., San Diego, CA, USA) showed less pharmacokinetic variability and reliable bioavailability compared with the diazepam rectal gel. Diazepam nasal spray could be considered as a suitable alternative for treating seizure emergencies outside the hospital. This review summarizes the treatment options for ARS and findings from clinical studies involving intranasal diazepam for treating seizure emergencies.
\end{abstract}

Keywords: acute repetitive seizures; diazepam; intranasal; rectal gel; rescue therapy

\section{Introduction}

An epileptic seizure is a neurologic condition marked by the occurrence of sudden and unpredictable interruption of neurons in the brain [1]. Epilepsy is characterized by two or more unprovoked seizures occurring $24 \mathrm{~h}$ apart. Approximately, $80 \%$ of seizures are unpredictable and sporadic, while $20 \%$ of seizures have a cyclical recurrence at somewhat predictable time intervals of days or weeks. Rare seizures occur in $\sim 1 \%$ and are instigated by specific precipitating events. Acute repetitive seizures (ARS) or seizure clusters are often observed in patients with epilepsy. The definition of ARS was proposed by the National Institutes of Health Epilepsy Advisory Committee in the mid-1990s. ARS is characterized by multiple seizures in less than $24 \mathrm{~h}$ for adults or in less than twelve hours for children. The duration of ARS may vary from a few minutes to several hours [2,3]. ARS arises due to unusual activities in the brain that may go unnoticed or may result in convulsions and unconsciousness due to uncontrolled body shakes. Epileptic seizures, including ARS, can develop at any stage and any age [4]. Children with recurrent seizures exhibit characteristic episodes of repetitive seizures distinctly different from their usual seizure behavior. The terms used to describe this phenomenon in the past include serial, cluster, recurrent, flurries, repetitive seizures, and crescendo seizures $[1,5]$.

According to the Center for Disease Control and Prevention, about 3,000,000 adults and 470,000 children in the USA are suffering from epilepsy [6]. The World Health Organization estimates 
over 50,000,000 people worldwide with epilepsy, of which approximately $80 \%$ are from low- and middle-income countries [7]. Generally, ARS is more common in patients with extratemporal epilepsy, specifically the frontal lobe epilepsy [8]. Other causes such as mesial temporal sclerosis [9], focal cortical dysplasia and a remote history of central nervous system infection are also shown to be associated with ARS [5,10]. Intractable epilepsy is also considered as a major risk factor for ARS with high average seizure frequency [10]. In most cases ARS is triggered due to sleep deprivation, hormonal changes during menstruation, stress, missing or changing medications, fever or illness, and alcohol $[5,9]$. Although, the overall percentage of the population with ARS is relatively small, those affected with ARS are at risk of medical complications, including injury, progression into status epilepticus and reduced quality of life. Given the substantial risks with ARS, it is necessary to develop appropriate protocols for identification and management of this seizure phenomenon [11]. The immediate care for ARS should often begin at home, before an emergency visit to a clinic [12]. Thus, it is crucial to treat short-term seizure recurrence, such as in ARS, to prevent its progression to prolonged seizures or status epilepticus. This review intends to provide an overview of treatment options for ARS, while emphasizing on clinical studies on the delivery of diazepam via the intranasal route.

\section{Treatment Options for ARS}

Drugs used in the management of seizure emergencies should (i) exhibit a rapid onset of action within a few minutes, (ii) be potent to permit small dose volumes, (iii) have a wide therapeutic index, and (iv) have an intermediate duration of action for a few hours. The major target for antiseizure drugs is the $\mathrm{GABA}_{\mathrm{A}}$ receptor $\left(\mathrm{GABA}_{\mathrm{A}} \mathrm{R}\right)$, which are found in the limbic system of the brain. Benzodiazepines (BZDs) are considered as the treatment of choice for acute management of severe seizures in both adults and children, except in infants less than two weeks of age in whom phenobarbitone is preferred [13]. Benzodiazepines are known to be positive allosteric modulators of $\mathrm{GABA}_{\mathrm{A}}$ receptors. These receptors are chloride-selective ligand-gated ion channels that are activated by GABA (one of the major inhibitory neurotransmitter in the brain). Binding of GABA is promoted when benzodiazepines bind to this receptor complex. This leads to an increase in conduction of chloride ions across the neuronal cell membrane resulting in hyperpolarizing of the neuronal cell membrane potential. Thus, there is a significant increase in the difference between resting and threshold potential leading to the reduction of neuron firing [14].

Evidence suggests that repetitive seizures can produce lasting morphological cortical brain damage [15], and the treatment efficacy decreases with an increase in the duration of seizure [16]. Therefore, immediate care by a caregiver should begin with the onset of seizures to maximize the treatment efficacy. This approach is popularly known as rescue therapy. Parenteral administration (intravenous or intramuscular) of antiepileptic drugs by a medical personnel results in an average treatment initiation time of approximately $85 \mathrm{~min}$. Intravenous (IV) administration of benzodiazepines is preferred in a hospital setting as it offers the fastest onset of action. Lorazepam, diazepam and midazolam are the most commonly administered IV preparations. These drugs have the same mechanism of action; however, the variation in their physicochemical and pharmacokinetic properties has clinical implications. For instance, the lipid solubility of benzodiazepines may vary by more than 3 times depending on the electronegative substituents. The octanol/buffer partition ratios of diazepam, lorazepam and midazolam at physiological $\mathrm{pH}$ are 309, 73 and 34, respectively [17]. The presence of methyl group in the benzodiazepine skeleton of diazepam contributes to its lipophilicity (Figure 1) [18]. The $\log \mathrm{P}$ value of a drug determines its lipid solubility and the rate at which a drug diffuses across biological barriers, i.e., the greater a drug's lipid solubility, the faster its absorption across the tissue membranes [19]. Diazepam results in higher brain concentrations with an onset of action of $\sim 30 \mathrm{~s}$ as it is highly lipophilic compared to lorazepam and midazolam. However, its high lipid solubility results in rapid in vivo redistribution into peripheral tissues, leading to a decrease in brain concentrations. The clinical effectiveness of diazepam is $\sim 20 \mathrm{~min}$, and mostly a second drug is required to reduce the relapse rate if diazepam is used as a first-line drug [20]. On the other hand, lorazepam has a slightly 
lower onset of action ( $\sim \mathrm{min})$ and its duration of action is greater than $12 \mathrm{~h}$ due to less lipid solubility compared to diazepam. The pharmacokinetic parameters of these drugs following IV administration are presented in Table 1. Intravenous administration is not possible when a patient with epilepsy has breakthrough or cluster seizures outside of medical facilities such as home, day care, school or work. Moreover, IV administration is associated with side effects such cardiac dysrhythmias, hypotension and depression of the CNS. As a result, there is a lot of interest in alternate out-of-hospital rescue therapies given by other routes of administration, such as oral, rectal, nasal and buccal routes [21].<smiles>CN1C(=O)CN=C(c2ccccc2)c2cc(Cl)ccc21</smiles>

A<smiles>O=C1Nc2ccc(Cl)cc2C(c2ccccc2Cl)=NC1O</smiles>

B<smiles>Cc1ncc2n1-c1ccc(Cl)cc1C(c1ccccc1F)=NC2</smiles>

Figure 1. Structure of diazepam (A), lorazepam (B), midazolam (C).

Table 1. Pharmacokinetic parameters of diazepam, midazolam and lorazepam following intravenous administration [22,23].

\begin{tabular}{|c|c|c|c|c|c|c|}
\hline Drug & $\begin{array}{c}\text { Volume of } \\
\text { Distribution } \\
\left(\mathrm{V}_{\mathrm{d}}\right), \mathrm{L} / \mathrm{kg}\end{array}$ & $\begin{array}{l}\text { Clearance } \\
\text { (L/h/Kg) }\end{array}$ & $\begin{array}{c}\text { Distribution } \\
\text { Half-Life } \\
\left(t_{1 / 2 \alpha}\right) \text { (min) }\end{array}$ & $\begin{array}{c}\text { Elimination } \\
\text { Half-Life } \\
\left(t_{1 / 2 \beta}\right) \text { (min) }\end{array}$ & $\begin{array}{c}\text { Onset of } \\
\text { Action (min) }\end{array}$ & Duration of Action \\
\hline Diazepam & $0.89 \pm 0.18$ & $0.0388 \pm 0.015$ & $1.9-13.3$ & $32.9 \pm 8.8$ & $1-3$ & $<2 \mathrm{~h}$ \\
\hline Midazolam & $0.80 \pm 0.19$ & $0.42 \pm 0.17$ & $18.6 \pm 14.4$ & $2.4 \pm 0.8$ & $\sim 2$ & $3-4 h$ \\
\hline Lorazepam & $1.14 \pm 0.03$ & $0.063 \pm 0.009$ & $<11$ & $14.3 \pm 2.5$ & $1-3$ & $<72 \mathrm{~h}$ \\
\hline
\end{tabular}

An ideal treatment option for ARS should be effective against a variety of seizure types, rapidly absorbed with a swift onset of action and consistent interpatient bioavailability, easily prepared and administered by anyone (including the patient during the intervals when consciousness is not altered), have a sustained duration of action with minimal side effects. In the 1990s, rectal diazepam gel (Diastat ${ }^{\circledR}$, Valeant Pharmaceuticals North America LLC, Bridgewater, NJ, USA) was approved by the FDA to abort acute seizures. Rectal administration of diazepam results in a rapid absorption because of high vascularity. Diazepam after rectal administration showed approximately 80-90\% bioavailability with an average peak concentration $\left(C_{\max }\right)$ occurring 10-60 min following the drug administration (Table 2). After rectal administration, therapeutic concentration of diazepam in plasma $(>200 \mathrm{ng} / \mathrm{mL})$ was reached within five to ten minutes, similar to both IV and IM administration. Diastat ${ }^{\circledR}$ has altered the seizure management plans in many patients; however, its use remained controversial mainly because of social and legal concerns [24]. Rectal lorazepam is effective in reducing seizures but shows high and variable bioavailability. Rectal administration is considered socially awkward in a non-private setting and caregivers administering rectal diazepam are worried about the risk of allegations of sexual abuse $[25,26]$. Also, it might be difficult to administer in patients confined to a wheelchair. Until the recent past, diazepam rectal gel is the only product available for use in immediate out of the hospital care for ARS in the United States at a dose of 0.2 to $0.5 \mathrm{mg} / \mathrm{kg}$, depending on age and weight [27]. In 2012, buccal midazolam (Buccolam ${ }^{\circledR}$, Viropharma, Downingtown, PA, USA) was approved by the European Medicines Agency (EMA) for the treatment of acute and prolonged convulsive seizures in 3 months old infants to adolescents ( $<18$ years). Sublingual lorazepam showed efficacy in the management of serial seizures in children [28]. Expidet ${ }^{\circledR}$ (Temesta, Pfizer, Germany) is an orodispersible tablet of lorazepam approved in Europe for the treatment of acute seizures in children [21]. However, buccal 
route is associated with limitations such as jaw clenching [29], hypersalivation, and uncontrollable swallowing resulting in variable pharmacodynamics [30]. A list of marketed products for treating ARS is presented in Table 3.

Table 2. Pharmacokinetic parameters of diazepam following various routes of administration [31-33].

\begin{tabular}{cccc}
\hline Route of Administration & Onset of Action (min) & Peak Plasma Levels (min) & Bioavailability \\
\hline Oral & $15-60$ & $30-90$ & $100 \%$ \\
\hline IM & $15-30$ & $30-60$ & $60 \%$ \\
\hline Rectal & $5-10$ & $10-45$ & $80-90 \%$ \\
\hline Intranasal & $<5$ & $>60$ & $97 \%$ \\
\hline
\end{tabular}

Table 3. List of marketed products for acute repetitive seizures.

\begin{tabular}{|c|c|c|c|}
\hline Drug & Brand Name & Route & Excipients \\
\hline Diazepam & Valium ${ }^{\circledR}$ & Intravenous & $\begin{array}{l}40 \% \text { propylene glycol, } 10 \% \text { ethyl alcohol; } \\
5 \% \text { Na benzoate and, benzoic acid as } \\
\text { buffers, and } 1.5 \% \text { benzyl alcohol as a } \\
\text { preservative [34]. }\end{array}$ \\
\hline Diazepam & Diastat ${ }^{\circledR}$ & Rectal & $\begin{array}{l}\text { Propylene glycol, ethyl alcohol (10\%), } \\
\text { hydroxypropyl methylcellulose, sodium } \\
\text { benzoate, benzyl alcohol (1.5\%), benzoic } \\
\text { acid and water. }\end{array}$ \\
\hline Diazepam & $\begin{array}{l}\text { Valtoco }{ }^{\circledR} \\
\text { Available doses: } 5 \mathrm{mg}, 10 \mathrm{mg}, 15 \mathrm{mg} \text { ) }\end{array}$ & Intranasal & $\begin{array}{l}\text { Benzyl alcohol (10.5 mg per } 0.1 \mathrm{~mL}) \text {, } \\
\text { dehydrated alcohol, n-dodecyl } \\
\text { beta-D-maltoside, and vitamin E. }\end{array}$ \\
\hline Lorazepam & Temesta ${ }^{\circledR}$, solution for injection & Intravenous & $\begin{array}{l}\text { Macrogol 400, benzyl alcohol } 21 \mathrm{mg} / \mathrm{ml} \text {, } \\
\text { propylene glycol. }\end{array}$ \\
\hline Lorazepam & Temesta Expidet ${ }^{\circledR}$ & Orodispersible & Gelatin, mannitol \\
\hline Midazolam & Midazolam injection, USP & Intravenous & $\begin{array}{l}0.8 \% \text { sodium chloride and } 0.01 \% \text { edetate } \\
\text { disodium, with } 1 \% \text { benzyl alcohol as } \\
\text { preservative; the } \mathrm{pH} \text { is adjusted to } 3 \text { to } 3.6 \\
\text { with hydrochloric acid and, if necessary, } \\
\text { sodium hydroxide }\end{array}$ \\
\hline Midazolam & Seizalam ${ }^{\mathrm{TM}}$ & Intramuscular & $\begin{array}{l}1 \% \text { benzyl alcohol as preservative, } 0.01 \% \\
\text { edetate disodium, and } 0.8 \% \text { sodium } \\
\text { chloride, } \mathrm{pH} \text { is adjusted to } \sim 3 \text {. }\end{array}$ \\
\hline Midazolam & Nayzilam ${ }^{\circledR}$ & Intranasal & $\begin{array}{l}\text { Ethanol, PEG-6 methyl ether, polyethylene } \\
\text { glycol 400, propylene glycol and } \\
\text { purified water. }\end{array}$ \\
\hline $\begin{array}{l}\text { Midazolam } \\
\text { hydrochloride }\end{array}$ & Buccolam $^{\circledR}$ & $\begin{array}{l}\text { Oromucosal } \\
\text { solution }\end{array}$ & $\begin{array}{l}\text { Sodium chloride, water for injections, } \\
\text { hydrochloric acid (for } \mathrm{pH} \text { adjustment and } \\
\text { conversion of midazolam to the } \\
\text { hydrochloride salt), sodium hydroxide (for } \\
\text { pH adjustment }\end{array}$ \\
\hline $\begin{array}{l}\text { Midazolam } \\
\text { maleate }\end{array}$ & Epistatus ${ }^{\circledR}$ & $\begin{array}{l}\text { Oromucosal } \\
\text { solution }\end{array}$ & $\begin{array}{l}\text { Ethanol, saccharin sodium, glycerol } \\
\text { purified water, sodium hydroxide (for } \mathrm{pH} \\
\text { adjustment), liquid maltitol }\end{array}$ \\
\hline
\end{tabular}

Intranasal route is considered as an attractive alternative to the rectal and buccal routes of diazepam administration [35,36]. Development of intranasal formulations of benzodiazepines such as diazepam is challenging due to solubility and absorption issues arising from their nonaqueous nature [37]. Recently, FDA has approved intranasal formulations of diazepam (NRL-1; Valtoco ${ }^{\circledR}$ ) and midazolam (USL261; Nayzilam ${ }^{\circledR}$, Proximagen, LLC, Plymouth, MN, USA) for use by a caregiver outside of a medical setting for acute treatment of intermittent, stereotypic episodes of frequent seizure activity (i.e., seizure clusters, acute repetitive seizures) [38]. NRL-1 is formulated with vitamin E to 
enhance diazepam's nonaqueous solubility and n-dodecyl $\beta$-D-maltoside (DDM, Intravail ${ }^{\circledR}$ A3, Aegis Therapeutics, LLC, San Diego, CA, USA), a nonionic surfactant, as an absorption enhancer to promote the transmucosal bioavailability of diazepam [38,39]. Intravail ${ }^{\circledR}$ excipients are designated as Generally Recognized as Safe (GRAS) substances for food applications [39]. Valtoco ${ }^{\circledR}$ (5 $\mathrm{mg}$ and $10 \mathrm{mg}$ doses) is generally administered as a single spray into one nostril, while higher doses of $15 \mathrm{mg}$ and $20 \mathrm{mg}$ doses requires two sprays, one spray into each nostril (Figure 2). To the best of our knowledge, very few review articles recapitulated the intranasal delivery approach for treating seizure emergencies and they are too generalized [37]. This review is mainly focused on the formulation approaches designed for intranasal delivery of diazepam for acute management of seizures.
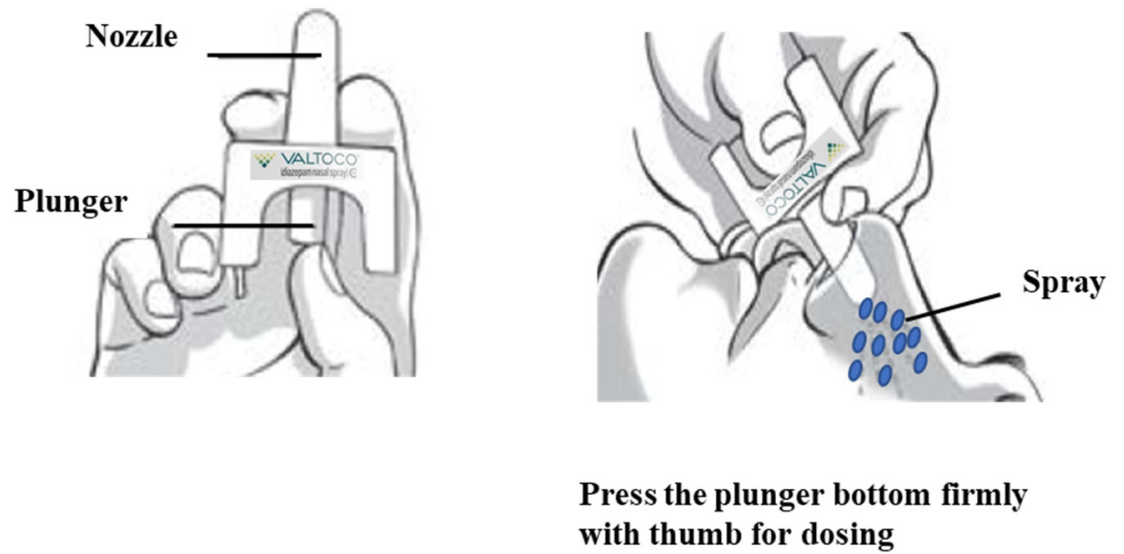

Figure 2. Application of Valtoco ${ }^{\circledR}$ diazepam nasal spray. Image modified from Valtoco ${ }^{\circledR}$ package insert.

\section{Diazepam for Intranasal Administration}

In the early 1980s, the nasal route was introduced as a promising alternative to the conventional delivery [40]. The nasal route is easily accessible and has a porous endothelial layer along with a highly vascularized epithelium to provide rapid absorption of drug compounds into the systemic circulation without first pass metabolism [41,42]. Other benefits of intranasal drug delivery include non-invasiveness, patient comfort and self-administration. The nasal cavity provides delivery of drugs ranging from small molecules to large macromolecules (proteins, peptides, hormones and vaccines) [43]. For information on formulation approaches for improved intranasal delivery of drugs the readers can refer to the review by Kapoor et al. [37]. Nasal route is favored to circumvent the obstacles of blood brain barrier (BBB) permitting direct drug delivery to the central nervous system (CNS). Nasally administered drugs can reach the brain via two pathways. In the direct pathway, drugs reach the brain via the olfactory and/trigeminal neuronal nerves, while in the indirect pathway, drugs are first absorbed into the systemic circulation and then reach the brain (graphical abstract) [37]. A study in New Zealand white rabbits and Sprague-Dawley rats showed that intranasal diazepam reached the brain predominantly via the indirect pathway with no significant direct nose-to-brain transport via olfactory epithelium and trigeminal neuronal nerves [44].

Diazepam, midazolam, lorazepam and clonazepam have been evaluated for intranasal administration as rescue therapy outside the hospital. Of these, midazolam exhibited a faster rate of absorption, while diazepam showed superior bioavailability and duration of action. The physicochemical properties of diazepam make it a good candidate for intranasal administration. Diazepam's lipid solubility and potency are comparable to midazolam; however, diazepam has a substantially longer elimination half-life, which provides a longer duration of action as compared to midazolam [45]. Following intranasal administration, midazolam exhibits faster rate of absorption, but lower and more variable absorption, and a shorter elimination half-life as compared to intranasal diazepam [22,46]. Lorazepam is long acting (up to $72 \mathrm{~h}$ ), with less risk of seizure recurrence. As compared with diazepam and midazolam, lorazepam has a slower redistribution from the brain due 
to its lower lipid solubility, resulting in a longer half-life. These properties make IV lorazepam a good choice for treating status epilepticus. In contrast, the lower lipid solubility of lorazepam makes it a less optimal candidate for intranasal administration due to slower rate of absorption and onset of action than midazolam and diazepam [47]. In a study, the efficacy of lorazepam administered via buccal, intranasal or IV routes were compared in Malawian children with acute seizures. This study concluded that lorazepam administered through intranasal and buccal routes was less effective compared to IV lorazepam [48]. Overall, intranasal diazepam has been considered as an attractive treatment option in ARS compared to other benzodiazepines.

Several studies have investigated the efficacy of intranasal diazepam in comparison with IV and rectal administration both in animals and humans. These studies have been highlighted in Table 4 . In this section we shall focus mainly on the safety and efficacy studies of intranasal diazepam conducted in humans. The first clinical trial of intranasal diazepam in comparison with IV administration was conducted by Gizurarson et al. Intranasal diazepam was prepared in 5\% glycofurol in polyethylene glycol 200. In this open crossover clinical trial, $2 \mathrm{mg}$ diazepam was administered in nine healthy volunteers both intranasally and intravenously. The results showed that the bioavailability was $50.4 \pm 23.3 \%$, and the peak concentration was achieved after $18 \pm 11 \mathrm{~min}$ following intranasal administration. The pharmacodynamic effect of diazepam was observed after $\sim 5 \mathrm{~min}$; however, IV administration failed to generate a strong measurable effect at such a low dose. Despite the transient nasal discomfort in subjects, this study concluded that intranasal diazepam could be an alternative to intranasal and IV administration for acute seizures [49]. A follow-up study by the same group assessed the electroencephalographic (EEG) effects, blood concentrations, vehicle irritation and dose-effect relationships of intranasal diazepam (dissolved in polyethylene glycol 300). Intranasal doses of 4 and $7 \mathrm{mg}$ diazepam were compared with $5 \mathrm{mg}$ IV dose in seven healthy volunteers. The relative bioavailability of 4 and $7 \mathrm{mg}$ doses of intranasal diazepam was 45 and $42 \%$ with a $C_{\max }$ of 99 and $179 \mathrm{ng} / \mathrm{mL}$ and $t_{\max }$ of 18 and $42 \mathrm{~min}$, respectively. The bioavailability of 4 and $7 \mathrm{mg}$ intranasal formulations were found to be almost similar, $45 \%$ and $42 \%$, respectively. EEG effects of the highest nasal dose $(7 \mathrm{mg})$ and the intravenous dose were found to be similar, whereas the nasal dose of $4 \mathrm{mg}$ produced a lower effect. This study pointed out that the lipophilic nature of diazepam promotes its distribution into the fatty tissue of the brain as the plasma concentration of the drug falls, resulting in a sustained pharmacodynamic effect. Nevertheless, this study did not choose to evaluate the existence of the direct nose-to-brain transport of diazepam. The authors concluded that PEG300 as a solubilizer of diazepam was found to be effective in the acute treatment of epilepsy [50].

Ivaturi and his colleagues studied the bioavailability, dose proportionality and tolerability of a supersaturated intranasal diazepam solubilized in a glycofurol-water cosolvent system in eight healthy volunteers [51]. A dose of 5 and $10 \mathrm{mg}$ intranasal diazepam of the investigational formulation (supersaturated solution containing $40 \mathrm{mg} / \mathrm{mL}$ of diazepam in glycofurol and water) was compared with a $5 \mathrm{mg}$ dose of IV diazepam. The median $\mathrm{t}_{\max }$ were 20 and $30 \mathrm{~min}$ and the mean $\mathrm{C}_{\max }$ were $134.3 \pm 62$ and $247.6 \pm 61 \mathrm{ng} / \mathrm{mL}$ for 5 and $10 \mathrm{mg}$ intranasal doses with an estimated bioavailability of $75 \%$ for both doses. This study reported reasonable bioavailability from intranasal diazepam with less tolerability as volunteers reported of discomfort after intranasal administration. This was attributed to the use of glycofurol in the intranasal formulation. In a subsequent study the same group assessed the pharmacokinetics and tolerability of investigational diazepam formulation and a parenteral midazolam following intranasal administration for treatment of seizure emergencies. Subjects received $5 \mathrm{mg}$ of diazepam and midazolam via both IV and intranasal routes in a four-way, randomized crossover trial. Both formulations exhibited rapid drug absorption following intranasal administration with temporary discomfort. The $\mathrm{C}_{\max }$ and $\mathrm{T}_{\max }$ values for intranasal midazolam and diazepam were $62.8 \mathrm{ng} / \mathrm{mL}$ and $21.6 \mathrm{~min}$ vs $179.2 \mathrm{ng} / \mathrm{mL}$ and $28.8 \mathrm{~min}$, respectively. Diazepam showed an extended duration of action due to a longer drug half-life. This study supported the usefulness of intranasal diazepam for treating seizure emergencies and emphasized on more research to understand the safety, efficacy and pharmacokinetics of intranasal diazepam in large patient populations [45]. 
Table 4. Preclinical and clinical pharmacokinetic studies related to the use of intranasal diazepam.

\begin{tabular}{|c|c|c|c|c|c|}
\hline $\begin{array}{c}\text { Formulations/Routes of } \\
\text { Administration }\end{array}$ & Study Design & Subjects & Results & Conclusions & Ref. \\
\hline $\begin{array}{l}\text { Intranasal diazepam }(10 \mathrm{mg}) \\
\text { and lorazepam }(4 \mathrm{mg}) \\
\text { formulated using non-ionic } \\
\text { surfactant (Cremophor EL) }\end{array}$ & Crossover trial & Healthy adults & $\begin{array}{l}\text { Diazepam: Bioavailability }=84 \% \text { and } 72 \% \text {, } \\
\mathrm{T}_{\max }=1 \mathrm{~h}, \mathrm{C}_{\max }=175 \mathrm{ng} / \mathrm{mL} \text {. Peak } \\
\text { concentration following intranasal } \\
\text { administration was } 27 \% \text { to that of IV } \\
\text { administration. } \\
\text { Lorazepam: Bioavailability: } 35-63 \%, \mathrm{~T}_{\max }= \\
0.5 \text { to } 4 \mathrm{~h}, \mathrm{C}_{\max }=18.7 \pm 5.9 \mathrm{ng} / \mathrm{mL}, \mathrm{C}_{\max }: \\
33-94 \% \text { to that following IV administration. }\end{array}$ & $\begin{array}{l}\text { Intranasal administration of } \\
\text { diazepam and lorazepam } \\
\text { would have limited } \\
\text { potential in the acute } \\
\text { treatment of seizures. }\end{array}$ & {$[52]$} \\
\hline $\begin{array}{l}\text { Intranasal diazepam in a } \\
\text { mixture of } 5 \% \text { glycofurol and } \\
\text { polyethylene glycol } 200 \text { versus } \\
\text { commercial IV diazepam } \\
\text { (Stesolid }{ }^{\circledR} \text { Dumex-Alpharma), } \\
2 \text { mg dose }\end{array}$ & Open crossover trail & Healthy students & $\begin{array}{l}\text { Intranasal diazepam: } \mathrm{C}_{\max }=39 \pm 17 \mathrm{ng} / \mathrm{mL} \text {, } \\
\mathrm{t}_{\max }=18 \pm 11 \mathrm{~min}, \mathrm{t}_{1 / 2}=17.8 \pm 15.5, \\
\mathrm{AUC}_{0-30 \mathrm{~min}}=1095 \pm 412 \mathrm{ng} \cdot \mathrm{min} / \mathrm{mL} \\
\text { Intravenous diazepam: }_{1} \mathrm{t}_{1 / 2}=14.4 \pm 7.0 \\
\mathrm{AUC}_{0-30 \mathrm{~min}}=2972 \pm 980 \text { ng.min } / \mathrm{mL}\end{array}$ & $\begin{array}{l}\text { Intranasal diazepam could } \\
\text { be an alternative to IV and } \\
\text { rectal administration for } \\
\text { treating acute seizures }\end{array}$ & [49] \\
\hline $\begin{array}{l}\text { Intranasal diazepam in } \\
\text { polyethylene glycol } 300 \text { ( } 4 \mathrm{mg} \\
\text { and } 7 \mathrm{mg} \text { dose) versus Stesolid } \\
\text { Novum }{ }^{\circledR} \text { intravenous } \\
\text { diazepam (5 mg dose) }\end{array}$ & $\begin{array}{l}\text { Double-blind, } \\
\text { randomized, } \\
\text { crossover design }\end{array}$ & $\begin{array}{l}\text { Healthy } \\
\text { volunteers }\end{array}$ & $\begin{array}{l}\text { Mean differences between before and after } \\
\text { drug administration values of P300-N100 } \\
\text { amplitude differences were }-0.9(6.5,4.7) \text {, } \\
-6.4(-10.1,-2,7),-8.6(-11.4,-5.8) \text { and } \\
-9.6(-12.1,-7.1) \text { for placebo, } 4 \mathrm{mg} \\
\text { intranasal, } 7 \mathrm{mg} \text { intranasal and } 5 \mathrm{mg} \\
\text { diazepam preparations, respectively. } 4 \text { and } 7 \\
\text { mg intranasal diazepam formulations } \\
\text { showed bioavailabilities of } 45 \% \text { and } 42 \% \text {, } \\
\text { respectively. }\end{array}$ & $\begin{array}{l}\text { Based on the } \\
\text { electroencephalographic } \\
\text { effects and blood } \\
\text { concentration data, } \\
\text { PEG300 may be used to } \\
\text { deliver effective nasal dose } \\
\text { of diazepam for the acute } \\
\text { treatment of epilepsy }\end{array}$ & [50] \\
\hline $\begin{array}{l}\text { Intranasal diazepam in ten } \\
\text { vehicles of different polarity to } \\
\text { achieve } t_{\max } \leq 5 \mathrm{~min}\end{array}$ & - & Rabbits & $\begin{array}{l}\text { Pure glycofurol } 75, \text { tetraethyleneglycol, } \\
\text { poly(ethylene glycol) } 200 \text { and } 30 \% \text { glycofurol } \\
\text { in tetraethyleneglycol showed very rapid } \\
\text { pharmacodynamic response }(1.5-3.5 \mathrm{~min}) \\
\text { compared to more polar liquids }\end{array}$ & $\begin{array}{l}\text { Water-free } \\
\text { low-molecular-weight } \\
\text { glycols might be used as an } \\
\text { alternative to IV injection } \\
\text { for acute situations. }\end{array}$ & [53] \\
\hline $\begin{array}{l}\text { Intranasal diazepam versus IV } \\
\text { diazepam }(0.5 \mathrm{mg} / \mathrm{kg})\end{array}$ & Crossover design & $\begin{array}{l}\text { Healthy adult } \\
\text { greyhounds }\end{array}$ & $\begin{array}{l}\text { IV: } C_{\text {peak }}: 1316 \pm 216 \mu \mathrm{g} / \mathrm{L}, \mathrm{T}_{\text {peak }} \text { was } \leq 3 \mathrm{~min} \\
\left.\text { Intranasal: } \mathrm{C}_{\text {peak }}: 448 \pm 41 \mu \mathrm{g} / \mathrm{L}\right), \mathrm{T}_{\text {peak }}: 4.5 \\
\pm 1.5 \text { min, Bioavailability: } 80 \pm 9 \%\end{array}$ & $\begin{array}{l}\text { Plasma concentrations } \\
\text { exceed } 300 \mu \mathrm{\mu g} / \mathrm{L} \\
\text { (therapeutic concentration). } \\
\text { Intranasal diazepam may be } \\
\text { useful for treatment of } \\
\text { seizures in dogs in place of } \\
\text { IV administration }\end{array}$ & [54] \\
\hline
\end{tabular}


Table 4. Cont.

\begin{tabular}{|c|c|c|c|c|c|}
\hline $\begin{array}{c}\text { Formulations/Routes of } \\
\text { Administration }\end{array}$ & Study Design & Subjects & Results & Conclusions & Ref. \\
\hline $\begin{array}{l}\text { Intranasal ethyl laurate-based } \\
\text { microemulsion systems of } \\
\text { diazepam }(1-2 \mathrm{mg} / \mathrm{kg}) \text { and } \\
\text { comparison with IV } \\
\text { administration }(1 \mathrm{mg} / \mathrm{kg}) \text {. }\end{array}$ & - & Rabbits & $\begin{array}{l}\text { Tween } 80-23.3 \% \text {, propylene glycol- } 23.3 \% \\
\text { ethanol- } 15 \% \mathrm{H}_{2} \mathrm{O} \text { at } 2 \mathrm{mg} / \mathrm{kg} \text { dose resulted } \\
\text { in rapid-onset of action ( } 2-3 \mathrm{~min} \text { ) of } \\
\text { diazepam with } 50 \% \text { bioavailability. }\end{array}$ & $\begin{array}{l}\text { Ethyl laurate-based } \\
\text { microemulsion of diazepam } \\
\text { may be useful in the } \\
\text { treatment of } \\
\text { status epilepticus. }\end{array}$ & [55] \\
\hline $\begin{array}{l}\text { Diazepam intranasal }(7 \mathrm{mg}) \\
\text { versus diazepam intravenous ( } 3 \\
\text { mg). Results were compared } \\
\text { with rabbit and human data }\end{array}$ & Crossover design & Sheep & $\begin{array}{l}\text { Mean nasal bioavailability, } \mathrm{t}_{\max } \text { and } \mathrm{C}_{\max } \\
\text { were } 15 \pm 8 \%, 5 \pm 3 \text { min and } 934 \pm 593 \\
\mathrm{ng} / \mathrm{mL} \text {, respectively. Bioavailability of } \\
\text { diazepam in sheep was lower than rabbit } \\
(54 \%, p<0.001) \text { and man }(34 \%, p<0.05) .\end{array}$ & $\begin{array}{l}\text { Correlation of } \\
\text { bioavailability (rate and the } \\
\text { extent of absorption) was } \\
\text { not optimal between sheep, } \\
\text { man and rabbit. }\end{array}$ & [56] \\
\hline $\begin{array}{l}\text { Supersaturated solution of } \\
\text { diazepam in glycofurol/water } \\
\text { for intranasal administration }\end{array}$ & - & $\begin{array}{l}\text { MDCK epithelial } \\
\text { cells as a nasal } \\
\text { mucosa model }\end{array}$ & $\begin{array}{l}\text { Steady-state flux of diazepam was obtained } \\
\text { across MDCK epithelial cell monolayers } \\
\text { from supersaturated solutions, which } \\
\text { increased proportionally with increasing } \\
\text { degree of saturation }\end{array}$ & $\begin{array}{l}\text { Supersaturated diazepam } \\
\text { solutions may be used for } \\
\text { intranasal delivery }\end{array}$ & [57] \\
\hline $\begin{array}{l}\text { Diazepam was intravenously }(1 \\
\mathrm{mg} / \mathrm{kg} \text { ) or intranasally }(2 \mathrm{mg} / \mathrm{kg}) \\
\text { administered to rats and rabbits }\end{array}$ & - & $\begin{array}{l}\text { New Zealand } \\
\text { white rabbits and } \\
\text { Sprague-Dawley } \\
\text { rats }\end{array}$ & $\begin{array}{l}\text { Rats: } \mathrm{T}_{\max }=5 \text { min in rats, } \\
\text { AUC } C_{\text {brain }} / \mathrm{AUC}_{\text {plasma }} \text { ratios after IV }(3.03 \pm \\
0.07) \text { and intranasal ( } 3.00 \pm 0.32) \\
\text { administration were nearly identical. } \\
\text { Bioavailability in rat plasma }(68.4 \%) \text { and } \\
\text { brain }(67.7 \%) \\
\text { Rabbits: } \mathrm{T}_{\max }=10 \mathrm{~min}, \\
\mathrm{AUC}_{\text {brain }} / \mathrm{AUC} \mathrm{C}_{\text {plasma }} \text { ratios after intranasal } \\
\text { administration }(3.77 \pm 0.17) \text { were slightly } \\
\text { lower than from IV administration }(4.23 \pm \\
0.08) \text {. Bioavailability in rabbit plasma }(51.6 \%) \\
\text { and brain }(45.9 \%)\end{array}$ & $\begin{array}{l}\text { No significant nose-to-brain } \\
\text { transport (via olfactory } \\
\text { epithelium) of diazepam } \\
\text { was observed. Diazepam } \\
\text { was mostly transported } \\
\text { acorss the blood-brain } \\
\text { barrier after intranasal } \\
\text { administration. }\end{array}$ & [44] \\
\hline $\begin{array}{l}\text { Intranasal diazepam } \\
\text { microemulsion }\end{array}$ & - & Bufo gargarizans & $\begin{array}{l}\text { Miglyol } 812(8.0 \%) \text {, Tween } 80(21.3 \%) \text {, } \\
\text { PEG400 (10.7\%) and water }(60.0 \%) \\
\text { containing microemulsion of diazepam } \\
\text { showed only slight nasal ciliotoxicity }\end{array}$ & $\begin{array}{l}\text { Microemulsions of Miglyol } \\
812-\text { Tween80-PEG400-water } \\
\text { system with diazepam } \\
\text { could be used for intranasal } \\
\text { administration }\end{array}$ & [58] \\
\hline $\begin{array}{l}5 \mathrm{mg} \text { of diazepam and } \\
\text { midazolam via both intranasal } \\
\text { and IV routes }\end{array}$ & $\begin{array}{l}\text { Four-way, randomized } \\
\text { crossover trial. }\end{array}$ & $\begin{array}{l}\text { Healthy adult } \\
\text { volunteers }\end{array}$ & $\begin{array}{l}\text { Diazepam: } C_{\max }=179.2^{\circ} \mathrm{ng} / \mathrm{mL}, \mathrm{T}_{\max }= \\
28.8 \mathrm{~min} \text { Midazolam: } \mathrm{C}_{\max }=62.8^{\circ} \mathrm{ng} / \mathrm{mL} \\
\text { and } \mathrm{T}_{\max } 21.6 \mathrm{~min} \text {. Intranasal administration } \\
\text { resulted in rapid absorption with transient } \\
\text { discomfort. Diazepam had a longer half-life, } \\
\text { with an extended duration of action }\end{array}$ & $\begin{array}{l}\text { Diazepam and midazolam } \\
\text { were rapidly absorbed } \\
\text { following intranasal } \\
\text { administration with } \\
\text { transient discomfort. }\end{array}$ & [45] \\
\hline $\begin{array}{l}\text { Intranasal formulation of } \\
\text { diazepam }(5 \mathrm{mg} \text { and } 10 \mathrm{mg}) \text { in a } \\
\text { glycofurol-water cosolvent } \\
\text { system was investigated }\end{array}$ & $\begin{array}{l}\text { Randomized, single-blind, } \\
\text { three-way crossover }\end{array}$ & $\begin{array}{l}\text { Healthy } \\
\text { volunteers }\end{array}$ & $\begin{array}{l}\text { The estimated bioavailability was } 75 \% \text { with } \\
\text { pain and tolerability scores around } 2-2.3 \text { and } \\
4.4-4.7 \text { following administration of } 5 \text { and } \\
10 \mathrm{mg} \text { doses, respectively }\end{array}$ & $\begin{array}{l}\text { Intranasal diazepam } \\
\text { provided a reasonable } \\
\text { bioavailability, but was not } \\
\text { well tolerated }\end{array}$ & [51] \\
\hline
\end{tabular}


Table 4. Cont

\begin{tabular}{|c|c|c|c|c|c|}
\hline $\begin{array}{c}\text { Formulations/Routes of } \\
\text { Administration }\end{array}$ & Study Design & Subjects & Results & Conclusions & Ref. \\
\hline $\begin{array}{l}\text { Alcohol-free microemulsion } \\
\text { system for intranasal delivery } \\
\text { of diazepam or midazolam } \\
\text { ( } 2.5 \% \text { by weight })\end{array}$ & $\begin{array}{l}\text { Randomized cross-over } \\
\text { design }\end{array}$ & Rabbits & $\begin{array}{l}\text { Diazepam: } C_{\max }=8.40 \pm 3.00, \text { Absolute } \\
\text { bioavailability }=33.45 \pm 12.36 \%, \\
t_{\max }=18.33 \pm 23.09 \min \\
\text { Midazolam: } C_{\max }=46.62 \pm 17.38, \mathrm{t}_{\max }=9.25 \\
\pm 6.75 \min , \text { Absolute bioavailability }=35.19 \\
\pm 11.83 \%\end{array}$ & $\begin{array}{l}\text { Midazolam and diazepam } \\
\text { microemulsion system } \\
\text { could achieve rapid-onset of } \\
\text { action following intranasal } \\
\text { administration }\end{array}$ & [59] \\
\hline $\begin{array}{l}\text { Pharmacokinetics of diazepam } \\
\text { following IV administration } \\
\text { versus administration as } \\
\text { intranasal drop versus } \\
\text { atomized nasal administration }\end{array}$ & Randomized block design & Dogs & $\begin{array}{l}\text { Mean diazepam concentrations following } \\
\text { intranasal administration reached } \\
>300 \mathrm{ng} / \mathrm{mL} \text { within } 5 \mathrm{~min} \text { in both groups. } \\
\text { Diazepam bioavailability after intranasal } \\
\text { drop and atomized nasal administration was } \\
42 \% \text { and } 41 \% \text {, respectively }\end{array}$ & $\begin{array}{l}\text { Intranasal administration } \\
\text { yielded rapid } \\
\text { anticonvulsant } \\
\text { concentrations of diazepam } \\
\text { in dogs }\end{array}$ & [60] \\
\hline $\begin{array}{l}\text { Effect of 1-menthol on } \\
\text { absorption of intranasal } \\
\text { diazepam }\end{array}$ & - & Mice & $\begin{array}{l}\text { The effect of diazepam via intranasal } \\
\text { administration was strengthened in the } \\
\text { presence of 1-menthol }\end{array}$ & $\begin{array}{l}\text { Intranasal diazepam with } \\
\text { l-menthol may result in } \\
\text { sedative-hypnotic action } \\
\text { and control epileptic } \\
\text { seizures }\end{array}$ & [61] \\
\hline $\begin{array}{l}\text { Effect of menthol as a } \\
\text { penetration enhancer on the } \\
\text { absorption intranasal diazepam }\end{array}$ & & Rabbit & $\begin{array}{l}\text { At } 0.2 \% \text {, menthol increased the absorption of } \\
\text { diazepam }[\mathrm{k}=(0.4424 \pm 0.0023) / \mathrm{h}] \text { with } \\
\text { quick absorption }\left[\mathrm{t}_{1 / 2}=(0.32 \pm 0.07) \mathrm{h}\right]\end{array}$ & $\begin{array}{l}0.2 \% \text { menthol helped in the } \\
\text { intranasal absorption of } \\
\text { diazepam through } \\
\text { passive diffusion }\end{array}$ & [62] \\
\hline $\begin{array}{l}\text { Tolerability and } \\
\text { pharmacokinetics of two } \\
\text { intranasal diazepam } \\
\text { formulations were compared } \\
\text { with rectal gel (Diastat }{ }^{\mathbb{R}} \text { ) }\end{array}$ & $\begin{array}{l}\text { Double blind, 4-period, } \\
\text { 4-way crossover study }\end{array}$ & $\begin{array}{l}\text { Healthy } \\
\text { volunteers }\end{array}$ & $\begin{array}{l}\text { Mean } \mathrm{C}_{\max }( \pm \mathrm{SD}) \text { was } 181.8 \pm 84.16 \\
151.3 \pm 108.1 \mathrm{and} 180.7 \pm 82.1 \mathrm{ng} / \mathrm{mL} \text { for } \\
\text { Nas-A } 10 \mathrm{mg}, \text { Nas-B } 10 \mathrm{mg} \text { and Nas-B } \\
13.4 \mathrm{mg} \text { respectively; while } \mathrm{C}_{\mathrm{max}} \text { for the } \\
\text { rectal gel was } 160.9 \pm 109.4 \mathrm{ng} / \mathrm{mL} \text {. Median } \\
\mathrm{t}_{\max } \text { was } 0.75 \mathrm{~h} \text { for all treatments. Intranasal } \\
\text { formulations were well tolerated and } \\
\text { exhibited relatively rapid but variable } \\
\text { absorption with bioavailability of } 70-90 \% \\
\text { compared to diazepam rectal gel }\end{array}$ & $\begin{array}{l}\text { Intranasal diazepam could } \\
\text { be an alternative to } \\
\text { rectal diazepam }\end{array}$ & [63] \\
\hline $\begin{array}{l}\text { Dose proportionality of } 5 \mathrm{mg} \\
\text { and } 20 \mathrm{mg} \text { of intranasal } \\
\text { diazepam formulations. } \\
\text { Relative bioavailability of } 20 \\
\mathrm{mg} \text { intranasal diazepam versus } \\
20 \mathrm{mg} \text { rectal gel }\end{array}$ & $\begin{array}{l}\text { Phase 1, single-center, } \\
\text { randomized, open-label, } \\
\text { three-period } \\
\text { crossover study }\end{array}$ & Healthy subjects & $\begin{array}{l}\text { Intranasal diazepam solutions }(5 \text { and } 20 \mathrm{mg}) \\
\text { showed dose proportionality with median } \\
\text { time to } C_{\text {max }} \text { of } 1 \mathrm{~h} \text {. Administration of a } \\
\text { single dose of } 20 \mathrm{mg} \text { intranasal diazepam } \\
\text { resulted in similar plasma concentrations of } \\
\text { diazepam and metabolite concentration, } \\
\text { with less variability than with } 20 \mathrm{mg} \\
\text { rectal gel }\end{array}$ & $\begin{array}{l}\text { Diazepam nasal solution ( } 20 \\
\mathrm{mg} \text { ) showed comparable } \\
\text { bioavailability as } 20 \mathrm{mg} \\
\text { rectal gel }\end{array}$ & [64] \\
\hline
\end{tabular}


Table 4. Cont

\begin{tabular}{|c|c|c|c|c|c|}
\hline $\begin{array}{l}\text { Formulations/Routes of } \\
\text { Administration }\end{array}$ & Study Design & Subjects & Results & Conclusions & Ref. \\
\hline $\begin{array}{l}\text { Diazepam nasal spray }(0.2 \\
\mathrm{mg} / \mathrm{kg})\end{array}$ & Open-label study & & $\begin{array}{l}T_{\max } \text { of diazepam was } 45 \text { min with } \\
\text { comparable dose-normalized mean } C_{\max } \\
\text { and } A U C_{0-12} \text { values of diazepam among } \\
\text { patients regardless of the timing of } \\
\text { administration in relation to seizure. }\end{array}$ & $\begin{array}{l}\text { Diazepam nasal spray could } \\
\text { be used during the } \\
\text { convulsive phase of } \\
\text { tonic-clonic seizures or in } \\
\text { the postictal periods } \\
\text { following tonic-clonic or } \\
\text { other seizure types. }\end{array}$ & [65] \\
\hline $\begin{array}{l}\text { Intranasal diazepam } \\
\text { formulation versus an } \\
\text { equivalent dose of rectal } \\
\text { diazepam }(20 \mathrm{mg})\end{array}$ & $\begin{array}{l}\text { Phase 1, open-label, } \\
\text { 3-period } \\
\text { crossover study. }\end{array}$ & Healthy adults & $\begin{array}{l}\text { Mean } C_{\max } \text { values of diazepam nasal spray } \\
\text { and rectal gel were found to be } 378 \pm 106 \\
\text { and } 328 \pm 152 \mathrm{ng} / \mathrm{mL} \text {, achieved at } 1.0 \text { and } \\
1.5 \mathrm{~h} \text {, respectively. Both intranasal and rectal } \\
\text { diazepam were well tolerated with mild to } \\
\text { moderate adverse events. }\end{array}$ & $\begin{array}{l}\text { Single-dose of } 20 \mathrm{mg} \\
\text { diazepam nasal spray is } \\
\text { tolerable and comparable in } \\
\text { bioavailability to that of } \\
\text { diazepam rectal gel. }\end{array}$ & [66] \\
\hline $\begin{array}{l}\text { Supersaturated diazepam } \\
\text { solution using a } \\
\text { prodrug/enzyme system } \\
\text { (Avizafone, a peptide prodrug } \\
\text { of diazepam, delivered } \\
\text { with-Aspergillus oryzae } \\
\text { protease) }\end{array}$ & - & $\begin{array}{l}\text { Madin-Darby } \\
\text { canine kidney } \\
\text { II-wild type }\end{array}$ & $\begin{array}{l}\text { Prodrug-protease mixtures upon apical } \\
\text { exposure onto MDCKKII-wt monolayers } \\
\text { showed 2-17.6-fold higher diazepam flux } \\
(\mathrm{S}=1.3-15.3) \text { compared to saturated } \\
\text { diazepam }(\mathrm{S}=0.7)\end{array}$ & $\begin{array}{l}\text { Intranasal } \\
\text { avizafone-protease system } \\
\text { with diazepam may provide } \\
\text { rapid delivery. }\end{array}$ & [67] \\
\hline $\begin{array}{l}\text { Effectiveness of intranasal } \\
\text { diazepam as an effective } \\
\text { alternative to IV diazepam } \\
\text { based on the medical records }\end{array}$ & Retrospective study & $\begin{array}{l}\text { Stroke patients } \\
\text { presenting with } \\
\text { status epilepticus. }\end{array}$ & $\begin{array}{l}\text { Intranasal diazepam was administered } 9 \\
\text { times faster compared to IV diazepam } \\
\text { resulting in about } 3 \text {-fold reduction in the } \\
\text { time to seizure activity termination } \\
\text { following arrival at the hospital ( } 3 \text { min vs } \\
9.5 \text { min in the IV group, } p=0.030 \text { ) }\end{array}$ & $\begin{array}{l}\text { Intranasal diazepam could } \\
\text { be a safe, quick and easier } \\
\text { alternative to } \\
\text { intravenous administration. }\end{array}$ & [68] \\
\hline $\begin{array}{l}\text { Diazepam-loaded } \\
\text { poly(lactic-co-glycolic acid) } \\
\text { nanoparticles }\end{array}$ & - & Rats & $\begin{array}{l}\text { Gamma scintigraphy using } \\
\text { technetium-99m-labeled ( } 99 \mathrm{mTc} \text { ) showed a } \\
\text { higher uptake of diazepam from } \\
\text { nanoparticles compared to diazepam } \\
\text { suspension in Sprague-Dawley rats. }\end{array}$ & $\begin{array}{l}\text { PLGA nanoparticles of } \\
\text { diazepam could be used in } \\
\text { the treatment of } \\
\text { status epilepticus }\end{array}$ & [69] \\
\hline $\begin{array}{l}\text { Mucoadhesive microemulsions } \\
\text { of diazepam for intranasal } \\
\text { administration versus } \\
\text { Calmpose (i.v) and } \\
\text { microemulsions }\end{array}$ & - & Rats & $\begin{array}{l}\text { Diazepam microemulsion composed of oleic } \\
\text { acid (5\%), surfactant mixture }(50 \%) \text {, water } \\
(45 \%) \text {, and chitosan }(0.5 \%) \text { showed } \\
\text { significantly high flux of } \\
846.96 \pm 34 \mu \mathrm{\mu g} / \mathrm{cm}^{2} / \mathrm{h} \text { and } \mathrm{AUC}_{\text {brain }}= \\
1206.49 \pm 145.8 \text { compared to Calmpose (i.v) } \\
\text { and microemulsion. }\end{array}$ & $\begin{array}{l}\text { Mucoadhesive } \\
\text { microemulsions showed } \\
\text { higher absorption } \\
\text { compared to } \\
\text { IV administration }\end{array}$ & [70] \\
\hline $\begin{array}{l}\text { Coadministration of a } \\
\text { hydrophilic diazepam prodrug } \\
\text { (avizafone) and converting } \\
\text { enzyme, human } \\
\text { aminopeptidase B }\end{array}$ & - & Rats & $\begin{array}{l}\text { Single doses of intranasal avizafone } \\
\text { equivalent to } 0.500,1.00, \text { and } 1.50 \mathrm{mg} / \mathrm{kg} \text { of } \\
\text { diazepam resulted in } 77.8 \% \pm 6.0 \% \text {, } \\
112 \% \pm 10 \% \text {, and } 114 \% \pm 7 \% \text { bioavailability } \\
\text { with } \mathrm{C}_{\max } \text { plasma concentrations } 71.5 \pm 9.3 \text {, } \\
388 \pm 31 \text {, and } 355 \pm 187 \mathrm{ng} / \mathrm{mL} \text {; and } \mathrm{t}_{\max } \text { of } 5 \text {, } \\
8 \text {, and } 5 \mathrm{~min} \text { for each dose level, respectively. }\end{array}$ & $\begin{array}{l}\text { Rapid and complete } \\
\text { absorption by } \\
\text { co-administering avizafone } \\
\text { with aminopeptidase B }\end{array}$ & [71] \\
\hline
\end{tabular}


Table 4. Cont.

\begin{tabular}{|c|c|c|c|c|c|}
\hline $\begin{array}{c}\text { Formulations/Routes of } \\
\text { Administration }\end{array}$ & Study Design & Subjects & Results & Conclusions & Ref. \\
\hline $\begin{array}{l}1 \text { dose period }(5,10 \text {, and } 20 \mathrm{mg}) \\
\text { followed by a } 2 \text {-dose period }(2 \\
\times 10 \mathrm{mg}) \text { with a minimum } \\
28 \text {-day washout }\end{array}$ & $\begin{array}{l}\text { Phase 1, open-label, } \\
\text { randomized, } \\
\text { crossover study }\end{array}$ & $\begin{array}{l}\text { Healthy adult } \\
\text { volunteers }\end{array}$ & $\begin{array}{l}\text { Plasma concentration-time profiles showed } \\
\text { similar patterns in a dose-dependent manner. } \\
\text { The } C_{\max } \text { values of diazepam were } 85.6, \\
133.6 \text {, and } 235.3 \mathrm{ng} / \mathrm{mL} \text { for } 5-, 10-\text {, and } 20 \text {-mg } \\
\text { doses, respectively. Dose-normalized } \\
\text { AUC } 0-\infty \text { values were comparable between } \\
\text { the } 2 \times 10 \text {-mg and single } 10-\mathrm{mg} \text { doses. }\end{array}$ & $\begin{array}{l}\text { NRL-1 could be a potential } \\
\text { therapy for managing } \\
\text { seizure emergencies. }\end{array}$ & [38] \\
\hline $\begin{array}{l}\text { Valtoco }^{\mathrm{TM}} \text { (NRL-1; diazepam } \\
\text { nasal spray) formulated with } \\
\text { Intravail }{ }^{\circledR} \text { A3 }\end{array}$ & Open-label study & $\begin{array}{l}\text { Patients with } \\
\text { epilepsy }\end{array}$ & $\begin{array}{l}\text { Pharmacokinetic parameters in } \\
\text { ictal/peri-ictal and inter-ictal conditions were } \\
\text { similar (tmax: } 3.31 \pm 2.10 \mathrm{vs.} 2.79 \pm 1.89 \text {; } \\
\mathrm{C}_{\max }: 156 \pm 17 \mathrm{vs} .179 \pm 18 \mathrm{ng} / \mathrm{mL} \text {; AUC: } \\
518 \pm 30 \mathrm{vs} .566 \pm 33 \mathrm{hr} \cdot \mathrm{ng} / \mathrm{mL} \text {, respectively) }\end{array}$ & $\begin{array}{l}\text { Valtoco }{ }^{\mathrm{TM}} \text { showed a good } \\
\text { safety profile in patients } \\
\text { with epilepsy }\end{array}$ & [72] \\
\hline $\begin{array}{l}\text { Bioavailability and tolerability } \\
\text { of intranasal diazepam } \\
\text { containing Intravail }^{\circledR} \text { vs } \\
\text { diazepam rectal gel }\end{array}$ & $\begin{array}{l}\text { Phase 1, open-label, } \\
\text { randomized, single-dose, } \\
\text { crossover study }\end{array}$ & $\begin{array}{l}\text { Healthy adult } \\
\text { subjects }\end{array}$ & $\begin{array}{l}T_{\max } \text { was similar for diazepam nasal spray } \\
\text { and rectal gel, which were slower than oral } \\
\text { diazepam in fasted individuals }\end{array}$ & $\begin{array}{l}\text { Intravail }{ }^{\circledR} \text { provided } \\
\text { therapeutic levels of } \\
\text { diazepam comparable to } \\
\text { rectal diazepam with no } \\
\text { damage to the nasal mucosa }\end{array}$ & [73] \\
\hline $\begin{array}{l}\text { Tolerability of NRL-1 (Valtoco }{ }^{\circledR} \text {, } \\
\text { diazepam nasal spray } \\
\text { formulated with Intravail A3) } \\
\text { and adverse events in patients }\end{array}$ & Open-label, Phase 3 study & $\begin{array}{l}\text { Adults and } \\
\text { children/adolescents } \\
\text { with epilepsy }\end{array}$ & $\begin{array}{l}\text { Of the } 57 \text { subjects, } 17 \text { subjects ( } 29.8 \%) \\
\text { reported treatment emergent adverse events } \\
\text { (TEAEs) with no treatment discontinuation. } \\
\text { Treatment-related TEAEs were observed in } 8 \\
\text { subjects (14\%). Dysgeusia was reported in } 3 \\
\text { subjects (5.3\%) and nasal discomfort in } \\
2 \text { subjects) }\end{array}$ & $\begin{array}{l}\text { NRL-1 demonstrated an } \\
\text { acceptable } \\
\text { safety/tolerability profile }\end{array}$ & [74] \\
\hline $\begin{array}{l}\text { Long-term safety and } \\
\text { tolerability of NRL-1 (Valtoco }{ }^{\circledR}, \\
\text { diazepam nasal spray } \\
\text { formulated with Intravail A3). } \\
\text { A dose of 5, 10, 15, or } 20 \mathrm{mg} \\
\text { was administered based on } \\
\text { patient weight }\end{array}$ & Phase 3, open-label, study & $\begin{array}{l}\text { Patients (including } \\
\text { adults and } \\
\text { children/adolescents }\end{array}$ & $\begin{array}{l}\text { Out of } 132 \text { enrolled subjects, NRL-1 was } \\
\text { used moderately in } 65(49.2 \%) \text { and } \\
\text { frequently in } 67(50.8 \%) \text { patients. Overall, } 91 \\
\text { patients }(68.9 \%) \text { had TEAEs }\end{array}$ & $\begin{array}{l}\text { Repeat dosing of NRL-1 } \\
\text { showed an acceptable } \\
\text { safety/tolerability profile } \\
\text { similar to diazepam } \\
\text { administered via } \\
\text { other routes }\end{array}$ & [75] \\
\hline $\begin{array}{l}\text { Type of dosing errors and } \\
\text { extent as a substitution for the } \\
\text { ability of patients/caregivers to } \\
\text { properly administer NRL-1 }\end{array}$ & Phase 3, open-label, study & $\begin{array}{l}\text { Pediatric and } \\
\text { adult patients with } \\
\text { epilepsy }\end{array}$ & $\begin{array}{l}\text { Patients/caregivers reported } 31 \text { dosing errors } \\
\text { in } 23 \text { patients }(1.2 \% \text { of the administered } 2486 \\
\text { doses). } 80.6 \% \text { of these errors were associated } \\
\text { with doses requiring spray into both nostrils } \\
\text { and } 4 \text { patients had multiple errors. Partial } \\
\text { dosing errors were } 48.4 \% \text {, improper dosing } \\
\text { errors were } 12.9 \% \text {, mechanical dosing time } \\
\text { were } 9.7 \% \text { and } 29.0 \% \text { were } \\
\text { other/unknown errors. }\end{array}$ & $\begin{array}{l}\text { Most errors occurred when } \\
\text { dose administration is } \\
\text { required into both nostrils }\end{array}$ & [76] \\
\hline
\end{tabular}


In a follow-up study the pharmacokinetics of newly designed, better tolerating intranasal formulations and rectal gel of diazepam were compared. Nasal formulations such as $10 \mathrm{mg}$ diazepam nasal formulation (Nas-A), $10 \mathrm{mg}$ diazepam nasal formulation (Nas-B1) and $13.4 \mathrm{mg}$ diazepam nasal formulation (Nas-B2) were compared with $10 \mathrm{mg}$ rectal diazepam. While the components of nasal formulations were not disclosed, the authors mentioned that excipients used in marketed ophthalmic preparation were utilized with a considerably higher aqueous component. The data from this study suggested that the absorption profile from the nasal spray and rectal gel are very similar. $T_{\max }$ attained was between 30 to $60 \mathrm{~min}$ post dose and the concentration of diazepam was above threshold for up to $12 \mathrm{~h}$. The maximum concentrations of intranasal formulations were in the range of 150-190 $\mathrm{ng} / \mathrm{mL}$. No clear advantage in pharmacokinetics was observed for either Nas-A or Nas-B, and their relative bioavailability was in the range of $70-90 \%$. Nasal formulation was found to be comparable to rectal gel in bioavailability. Incorporation of GRAS approved excipients in the nasal formulation resulted in better tolerability. This made intranasal administration of diazepam a viable alternative. This study also noted a wide intra-individual variability regardless of the route of administration [63]. Further study of the newly designed, better tolerable intranasal formulations were compared with a $5 \mathrm{mg}$ IV dose of commercially available diazepam injectable in 24 healthy volunteers. Intranasal diazepam solution resulted in an absolute bioavailability of $97 \%$ with $\mathrm{T}_{\max }$ value of $1.5 \mathrm{~h}$ and half-life of approximately $49 \mathrm{~h}$. This study concluded that the tested intranasal solution of diazepam resulted in high bioavailability, good tolerability, and reasonable variability [32]. This study unlike the previous studies did not report any nasal irritation; however, the issue of intersubject variability remained.

Herbert et al. in collaboration with Acorda Therapeutics (New York, NY, USA) developed a nasal spray of diazepam and evaluated its tolerability and bioavailability relative to rectal diazepam in 24 healthy adults. The nasal spray of diazepam was prepared using inactive ingredients such as methyl laurate, diethylene glycol monoethyl ether, N-methyl-2-pyrrolidone, propylene glycol monocaprylate, ethanol and water. Two intranasal doses of $5 \mathrm{mg}$ and $20 \mathrm{mg}$ were used in dose proportionality studies. The mean $\mathrm{C}_{\max }$ values for $20 \mathrm{mg}$ intranasal diazepam and rectal diazepam were $378 \pm 106$ and $328 \pm 152 \mathrm{ng} / \mathrm{mL}$ with $\mathrm{T}_{\max }$ values of 1.0 and $1.5 \mathrm{~h}$, respectively. Subjects administered intranasal and rectal gel formulations experienced nasal and rectal leakage, respectively. This study concluded that a single-dose of $20 \mathrm{mg}$ intranasal diazepam was comparable to rectal diazepam in terms of tolerability and bioavailability. Non treatment-emergent adverse events such as headache was reported in a few volunteers administered with $20 \mathrm{mg}$ intranasal diazepam [66]. The same group further examined the dosing feasibility and tolerability of intranasal diazepam (single dose of $0.2 \mathrm{mg} / \mathrm{kg}$ ) in adults with epilepsy. This pharmacokinetic study showed that a single dose can be effectively administered to adult patients either during or immediately after seizures. The differences in breathing patterns, body position or seizure type had no impact on the effectiveness of spray since the $C_{\max }$ and AUC values were comparable in different types of seizures. Even though a few patients faced nasal discharge immediately after dosing, the drug was rapidly absorbed. The data from 30 subjects showed that diazepam levels reached a mean concentration of $158 \pm 57.2 \mathrm{ng} / \mathrm{mL}$ by $15 \mathrm{~min}$ following dose administration and gradually reduced to $77 \mathrm{ng} / \mathrm{mL}$ by $12 \mathrm{~h}$. Based on the pharmacokinetic parameters, this study concluded that the discharge did not have a significant effect on the loss of diazepam. The plasma concentration of diazepam was reported to be sustained over $12 \mathrm{~h}$ and was within the reported range to display anticonvulsant effects. This study concluded that the intranasal diazepam has the potential to provide patients with a treatment option that offers greater freedom of movement beyond their local communities and emergency medical support, while addressing the issues of inconvenience and social embarrassment associated with rectal administration [65]. However, this study did not compare the efficacy their formulation against diazepam rectal gel in treating seizure clusters.

In 2016, Acorda Therapeutics Inc. published a press release reporting that Plumiaz nasal spray containing diazepam did not show good absorption across the lining of the nose in comparison with rectal diazepam or Diastat AcuDial [77]. Later in 2017, Neurelis Inc. (San Diego, CA, USA) announced 
that the US FDA has designated NRL-1 (intranasal diazepam) on a Fast Track Development program for the management of selected, refractory patients with epilepsy, on a stable regimen of anti-epileptic drugs (AEDs), who require intermittent use of diazepam to control bouts of increased seizures-also referred to as acute repetitive or cluster seizures [78]. NRL-1 (intranasal diazepam) is a nasal spray developed for the management of adult and pediatric patients that face ARS. In clinical trials, NRL-1 has demonstrated low variability, high bioavailability and was well-tolerated. This proprietary formulation of diazepam (NRL-1, Valtoco ${ }^{\circledR}$ ) has been granted Orphan Drug and Fast Track Designations by the FDA.

\section{Conclusions}

Epilepsy encompasses many syndromes and subsyndromes with a vast array of causes, effects and different underlying mechanisms. However, there are common mechanisms of seizure generation and propagation that can be successfully targeted by a single pharmacological agent. For instance, benzodiazepines are broadly effective across all seizure types and epilepsy syndromes, even though there are patients who are resistant to these drugs. Government organizations worldwide are trying to curb overall healthcare expenditure by encouraging patient-treatment through outpatient care models, such as clinic and home healthcare. Due to this reason, ARS market is expected to surge in the near future. The use of benzodiazepines as rescue medication in the management of ARS can help reduce healthcare-related expenses in patients due to decreased emergency room visits. Once delivered into the central nervous system, benzodiazepines are shown to be effective against a wide range of seizures with a rapid onset of action and thus can reduce emergency room visits. Intranasal diazepam has found a niche in alternate out-of-hospital rescue therapies of ARS, as several studies have demonstrated its undeniable positive effect on ARS. Diazepam nasal spray demonstrated an acceptable safety profile with less variation in the bioavailability compared with the rectal route. On the basis of pharmacokinetic results, tolerability and safety, diazepam nasal spray has the potential to be a game-changing treatment in ARS.

Current understanding of the mechanisms underlying epileptogenesis, seizure generation and seizure spread is advancing at an unprecedented pace, paving the way to the design and identify compounds that have the potential of improving the clinical outcomes in a staggering way. Major breakthroughs are being made in understanding the molecular deficits underlying many of these syndromes, including epileptic encephalopathies of childhood, making it possible to rationally design highly efficacious compounds precisely targeting the underlying etiological mechanisms. These modern advances will enable the investigation of antiepileptic drug pharmacology and facilitate the commercialization of new drug molecules by improving drug stability, solubility, decreasing dose frequency, and expanding routes of administration to address the unmet clinical needs. Further, technological advances in drug delivery allow researchers to administer drugs, control the rate of absorption and target them to a specific site. There is also a growing interest in seizure prediction using EEG recordings. The ability to predict seizures prior to onset, could transform the current mode of therapy to administering of medication well before the seizure occurs. Collaborative efforts among pharmaceutical scientists, physicians, and engineers are the need of the hour for invention of new technologies to improve the management of epilepsy.

Author Contributions: S.H.S.B.: the idea and layout, S.H.S.B., S.K., carried out literature search and initial drafting, S.H.S.B., S.K., data analysis and interpretation, S.H.S.B., manuscript editing, figures and tables. All authors have read and agreed to the published version of the manuscript.

Funding: This research received no external funding.

Acknowledgments: The authors would like to acknowledge Ajman University for its generous support.

Conflicts of Interest: The authors declare no conflict of interest. 


\section{References}

1. Cereghino, J.J. Identification and treatment of acute repetitive seizures in children and adults. Curr. Treat. Options Neurol. 2007, 9, 249-255. [CrossRef]

2. Cereghino, J.J.; Cloyd, J.C.; Kuzniecky, R.I.; The North American Diastat Study Group. Rectal diazepam gel for treatment of acute repetitive seizures in adults. Arch. Neurol. 2002, 59, 1915-1920. [CrossRef] [PubMed]

3. Buelow, J.M.; Shafer, P.; Shinnar, R.; Austin, J.; Dewar, S.; Long, L.; O’Hara, K.; Santilli, N. Perspectives on seizure clusters: Gaps in lexicon, awareness, and treatment. Epilepsy Behav. 2016, 57, 16-22. [CrossRef] [PubMed]

4. Liu, S.; Yu, W.; Lü, Y. The causes of new-onset epilepsy and seizures in the elderly. Neuropsychiatr. Dis. Treat. 2016, 12, 1425. [CrossRef] [PubMed]

5. Jafarpour, S.; Hirsch, L.J.; Gaínza-Lein, M.; Kellinghaus, C.; Detyniecki, K. Seizure cluster: Definition, prevalence, consequences, and management. Seizure 2019, 68, 9-15. [CrossRef] [PubMed]

6. Zack, M.M.; Kobau, R. National and State Estimates of the Numbers of Adults and Children with Active Epilepsy-United States, 2015. Mmwr. Morb. Mortal. Wkly. Rep. 2017, 66, 821-825. [CrossRef]

7. World Health Organization. Epilepsy. Available online: https://www.who.int/health-topics/epilepsy\#tab= tab_1 (accessed on 27 November 2020).

8. Haut, S.R. Seizure clustering. Epilepsy Behav. 2006, 8, 50-55. [CrossRef]

9. Komaragiri, A.; Detyniecki, K.; Hirsch, L.J. Seizure clusters: A common, understudied and undertreated phenomenon in refractory epilepsy. Epilepsy Behav. 2016, 59, 83-86. [CrossRef]

10. Chen, B.; Choi, H.; Hirsch, L.J.; Katz, A.; Legge, A.; Wong, R.A.; Jiang, A.; Kato, K.; Buchsbaum, R.; Detyniecki, K. Prevalence and risk factors of seizure clusters in adult patients with epilepsy. Epilepsy Res. 2017, 133, 98-102. [CrossRef]

11. McKee, H.R.; Abou-Khalil, B. Outpatient pharmacotherapy and modes of administration for acute repetitive and prolonged seizures. CNS Drugs 2015, 29, 55-70. [CrossRef]

12. Spencer, D. Hope for new treatments for acute repetitive seizures. Epilepsy Curr. 2014, 14, 147-149. [CrossRef] [PubMed]

13. Ciccone, O.; Mathews, M.; Birbeck, G.L. Management of acute seizures in children: A review with special consideration of care in resource-limited settings. Afr. J. Emerg. Med. 2017, 7, S3-S9. [CrossRef] [PubMed]

14. Greenfield, L.J., Jr. Molecular mechanisms of antiseizure drug activity at GABAA receptors. Seizure 2013, 22, 589-600. [CrossRef] [PubMed]

15. Thompson, P.J.; Duncan, J.S. Cognitive decline in severe intractable epilepsy. Epilepsia 2005, 46, $1780-1787$. [CrossRef] [PubMed]

16. Kapur, J.; Macdonald, R.L. Rapid Seizure-Induced Reduction of Benzodiazepine and $\mathrm{Zn}^{2+}$ Sensitivity of Hippocampal Dentate Granule Cell GABA ${ }_{A}$ Receptors. J. Neurosci. 1997, 17, 7532-7540. [CrossRef] [PubMed]

17. Greenblatt, D.; Arendt, R.; Abernethy, D.R.; Giles, H.; Sellers, E.; Shader, R. In vitro quantitation of benzodiazepine lipophilicity: Relation to in vivo distribution. BJA Br. J. Anaesth. 1983, 55, 985-989. [CrossRef]

18. Adeyemo, M.A.; Idowu, S.O. Correlation of lipophilicity descriptors with pharmacokinetic parameters of selected benzodiazepines. Afr. J. Biomed. Res. 2016, 19, 213-218.

19. Agarwal, S.K.; Cloyd, J.C. Development of benzodiazepines for out-of-hospital management of seizure emergencies. Neurol. Clin. Pr. 2015, 5, 80-85. [CrossRef]

20. Manno, E.M. Status epilepticus: Current treatment strategies. Neurohospitalist 2011, 1, 23-31. [CrossRef]

21. Rogawski, M.A.; Heller, A.H. Diazepam buccal film for the treatment of acute seizures. Epilepsy Behav. 2019, 101, 106537. [CrossRef]

22. Ivaturi, V.D. Intranasal and Rectal Diazepam for Rescue Therapy: Assessment of Pharmacokinetics and Tolerability; Retrieved from the University of Minnesota Digital Conservancy: Twin Cities, MN, USA, 2020; Available online: http://hdl.handle.net/11299/100044 (accessed on 29 November 2020).

23. Rey, E.; Tréluyer, J.-M.; Pons, G. Pharmacokinetic optimisation of benzodiazepine therapy for acute seizures. Clin. Pharmacokinet. 1999, 36, 409-424. [CrossRef] [PubMed]

24. Maglalang, P.D.; Rautiola, D.; Siegel, R.A.; Fine, J.M.; Hanson, L.R.; Coles, L.D.; Cloyd, J.C. Rescue therapies for seizure emergencies: New modes of administration. Epilepsia 2018, 59, 207-215. [CrossRef] 
25. Detyniecki, K.; Van Ess, P.J.; Sequeira, D.J.; Wheless, J.W.; Meng, T.-C.; Pullman, W.E. Safety and efficacy of midazolam nasal spray in the outpatient treatment of patients with seizure clusters-A randomized, double-blind, placebo-controlled trial. Epilepsia 2019, 60, 1797-1808. [CrossRef]

26. Anderson, M. Buccal midazolam for pediatric convulsive seizures: Efficacy, safety, and patient acceptability. Patient Prefer. Adherence 2013, 7, 27. [CrossRef]

27. Sarma, A.K.; Khandker, N.; Kurczewski, L.; Brophy, G.M. Medical management of epileptic seizures: Challenges and solutions. Neuropsychiatr. Dis. Treat. 2016, 12, 467.

28. Malu, C.K.K.; Kahamba, D.M.; Walker, T.D.; Mukampunga, C.; Musalu, E.M.; Kokolomani, J.; Mayamba, R.M.K.; Wilmshurst, J.M.; Dubru, J.-M.; Misson, J.-P. Efficacy of sublingual lorazepam versus intrarectal diazepam for prolonged convulsions in Sub-Saharan Africa. J. Child Neurol. 2014, 29, 895-902. [CrossRef] [PubMed]

29. McIntyre, J.; Robertson, S.; Norris, E.; Appleton, R.; Whitehouse, W.P.; Phillips, B.; Martland, T.; Berry, K.; Collier, J.; Smith, S. Safety and efficacy of buccal midazolam versus rectal diazepam for emergency treatment of seizures in children: A randomised controlled trial. Lancet 2005, 366, 205-210. [CrossRef]

30. Von Blomberg, A.; Kay, L.; Knake, S.; Fuest, S.; Zöllner, J.P.; Reif, P.S.; Herrmann, E.; Balaban, Ü.; Schubert-Bast, S.; Rosenow, F.; et al. Efficacy, Tolerability, and Safety of Concentrated Intranasal Midazolam Spray as Emergency Medication in Epilepsy Patients During Video-EEG Monitoring. CNS Drugs 2020, 34, 545-553. [CrossRef] [PubMed]

31. Dhaliwal, J.S.; Saadabadi, A. Diazepam. In StatPearls [Internet]; StatPearls Publishing: Treasure Island, FL, USA, 2019.

32. Agarwal, S.K.; Kriel, R.L.; Brundage, R.C.; Ivaturi, V.D.; Cloyd, J.C. A pilot study assessing the bioavailability and pharmacokinetics of diazepam after intranasal and intravenous administration in healthy volunteers. Epilepsy Res. 2013, 105, 362-367. [CrossRef] [PubMed]

33. Hogan, R.E.; Tarquinio, D.; Sperling, M.R.; Klein, P.; Miller, I.; Segal, E.B.; Rabinowicz, A.L.; Carrazana, E. Pharmacokinetics and safety of VALTOCO (NRL-1; diazepam nasal spray) in patients with epilepsy during seizure (ictal/peri-ictal) and nonseizure (interictal) conditions: A phase 1, open-label study. Epilepsia 2020, 61, 935-943. [CrossRef]

34. Grower, M.F.; Russell, E.A., Jr.; Getter, L. Solubility of injectable valium in intravenous solutions. Anesth. Prog. 1978, 25, 158. [PubMed]

35. Wermeling, D.P.H.; Miller, J.L.; Archer, S.M.; Manaligod, J.M.; Rudy, A.C. Bioavailability and pharmacokinetics of lorazepam after intranasal, intravenous, and intramuscular administration. J. Clin. Pharmacol. 2001, 41, 1225-1231. [CrossRef] [PubMed]

36. Vyas, T.K.; Shahiwala, A.; Marathe, S.; Misra, A. Intranasal drug delivery for brain targeting. Curr. Drug Deliv. 2005, 2, 165-175. [CrossRef] [PubMed]

37. Kapoor, M.; Cloyd, J.C.; Siegel, R.A. A review of intranasal formulations for the treatment of seizure emergencies. J. Control. Release 2016, 237, 147-159. [CrossRef]

38. Tanimoto, S.; Pesco Koplowitz, L.; Lowenthal, R.E.; Koplowitz, B.; Rabinowicz, A.L.; Carrazana, E. Evaluation of Pharmacokinetics and Dose Proportionality of Diazepam After Intranasal Administration of NRL-1 to Healthy Volunteers. Clin. Pharmacol. Drug Dev. 2020, 9, 719-727. [CrossRef]

39. Maggio, E.T.; Pillion, D.J. High efficiency intranasal drug delivery using Intravail ${ }^{\circledR}$ alkylsaccharide absorption enhancers. Drug Deliv. Transl. Res. 2013, 3, 16-25. [CrossRef]

40. Ali, J.; Ali, M.; Baboota, S.; Kaur Sahni, J.; Ramassamy, C.; Dao, L. Potential of nanoparticulate drug delivery systems by intranasal administration. Curr. Pharm. Des. 2010, 16, 1644-1653. [CrossRef]

41. Arora, P.; Sharma, S.; Garg, S. Permeability issues in nasal drug delivery. Drug Discov. Today 2002, 7, 967-975. [CrossRef]

42. Ugwoke, M.I.; Verbeke, N.; Kinget, R. The biopharmaceutical aspects of nasal mucoadhesive drug delivery. J. Pharm. Pharmacol. 2001, 53, 3-22. [CrossRef]

43. Choi, H.-G.; Jung, J.-H.; Ryu, J.-M.; Yoon, S.-J.; Oh, Y.-K.; Kim, C.-K. Development of in situ-gelling and mucoadhesive acetaminophen liquid suppository. Int. J. Pharm. 1998, 165, 33-44. [CrossRef]

44. Kaur, P.; Kim, K. Pharmacokinetics and brain uptake of diazepam after intravenous and intranasal administration in rats and rabbits. Int. J. Pharm. 2008, 364, 27-35. [CrossRef]

45. Ivaturi, V.D.; Riss, J.R.; Kriel, R.L.; Cloyd, J.C. Pharmacokinetics and tolerability of intranasal diazepam and midazolam in healthy adult volunteers. Acta Neurol. Scand. 2009, 120, 353-357. [CrossRef] [PubMed] 
46. Schrier, L.; Zuiker, R.; Merkus, F.W.H.M.; Klaassen, E.S.; Guan, Z.; Tuk, B.; van Gerven, J.M.A.; van der Geest, R.; Groeneveld, G.J. Pharmacokinetics and pharmacodynamics of a new highly concentrated intranasal midazolam formulation for conscious sedation. Br. J. Clin. Pharmacol. 2017, 83, 721-731. [CrossRef] [PubMed]

47. French, J.A. Benzo versus benzo: And the winner is ... . Epilepsy Curr. 2011, 11, 143-144. [CrossRef] [PubMed]

48. Lissauer, S.; Kenny, J.; Jefferis, O.; Wingfield, T.; Miller, A.; Chagaluka, G.; Kalilani-Phiri, L.; Molyneux, E. Buccal, intranasal or intravenous lorazepam for the treatment of acute convulsions in children in Malawi: An open randomized trial: Le lorazépam par voie orale, intranasale ou intraveineuse pour le traitement des convulsions aiguës chez l'enfant au Malawi: Étude ouverte randomisée. Afr. J. Emerg. Med. 2015, 5, 120-126.

49. Gizurarson, S.; Gudbrandsson, F.K.; Jonsson, H.; Bechgaard, E. Intranasal administration of diazepam aiming at the treatment of acute seizures: Clinical trials in healthy volunteers. Biol. Pharm. Bull. 1999, 22, 425-427. [CrossRef]

50. Lindhardt, K.; Gizurarson, S.; Stefánsson, S.B.; Òlafsson, D.R.; Bechgaard, E. Electroencephalographic effects and serum concentrations after intranasal and intravenous administration of diazepam to healthy volunteers. Br. J. Clin. Pharm. 2001, 52, 521-527. [CrossRef]

51. Ivaturi, V.D.; Riss, J.R.; Kriel, R.L.; Siegel, R.A.; Cloyd, J.C. Bioavailability and tolerability of intranasal diazepam in healthy adult volunteers. Epilepsy Res. 2009, 84, 120-126. [CrossRef]

52. Lau, S.W.J.; Slattery, J.T. Absorption of diazepam and lorazepam following intranasal administration. Int. J. Pharm. 1989, 54, 171-174. [CrossRef]

53. Bechgaard, E.; Gizurarson, S.; Hjortkjær, R.K. Pharmacokinetic and Pharmacodynamic Response after Intranasal Administration of Diazepam to Rabbits. J. Pharm. Pharmacol. 1997, 49, 747-750. [CrossRef]

54. Platt, S.R.; Randell, S.C.; Scott, K.C.; Chrisman, C.L.; Hill, R.C.; Gronwall, R.R. Comparison of plasma benzodiazepine concentrations following intranasal and intravenous administration of diazepam to dogs. Am. J. Vet. Res. 2000, 61, 651-654. [CrossRef] [PubMed]

55. Li, L.; Nandi, I.; Kim, K.H. Development of an ethyl laurate-based microemulsion for rapid-onset intranasal delivery of diazepam. Int. J. Pharm. 2002, 237, 77-85. [CrossRef]

56. Lindhardt, K.; Ólafsson, D.R.; Gizurarson, S.; Bechgaard, E. Intranasal bioavailability of diazepam in sheep correlated to rabbit and man. Int. J. Pharm. 2002, 231, 67-72. [CrossRef]

57. Hou, H. Development of Novel Intranasal Diazepam Formulations for the Treatment of Seizure Emergencies; University of Minnesota: Minneapolis, MN, USA, 2006.

58. Jiao, C.-M.; Liu, H.-Z.; Jing, L.-Y.; Zhang, Y.; Li, S.-M. Preparation and evaluation of diazepam microemulsion for intranasal delivery. Chin. J. Pharm. 2008, 4, 1-284.

59. Botner, S.; Sintov, A.C. Intranasal Delivery of Two Benzodiazepines, Midazolam and Diazepam, by a Microemulsion System. Pharmacol. Pharm. 2011, 9. [CrossRef]

60. Musulin, S.E.; Mariani, C.L.; Papich, M.G. Diazepam pharmacokinetics after nasal drop and atomized nasal administration in dogs. J. Vet. Pharmacol. Ther. 2011, 34, 17-24. [CrossRef]

61. Sheng, P.; Zhang, R.-T.; Wang, H.; Nie, H.; Fu, X.-H. The effect of 1-menthol on the intranasal absorption to diazepam. Chin. J. Hosp. Pharm. 2012, 24, 172-182.

62. Sheng, P.; Zhang, R.-T.; Wang, H.; Huang, Z.; Fu, X.-H. Intranasal Absorption Kinetics of Diazepam and Promoting Effect of Menthol on The Absorption of Diazepam. Eval. Anal. Drug Use Hosp. China 2013, 19, $34-40$.

63. Ivaturi, V.; Kriel, R.; Brundage, R.; Loewen, G.; Mansbach, H.; Cloyd, J. Bioavailability of Intranasal vs. Rectal Diazepam. Epilepsy Res. 2013, 103, 254-261. [CrossRef]

64. Bream, G.; Leibowitz, M.; Wargin, B.; Abernathy, K.; Henney, H.; Ward, D. Assessment of Pharmacokinetic Linearity and Relative Bioavailability of an Intranasal Diazepam Formulation Compared with Diazepam Rectal Gel in Healthy Adult Subjects (P02. 214); AAN Enterprises: St. Paul, MN, USA, 2013.

65. Sperling, M.R.; Haas, K.F.; Krauss, G.; Seif Eddeine, H.; Henney, H.R.; Rabinowicz, A.L.; Bream, G.; Squillacote, D.; Carrazana, E.J. Dosing feasibility and tolerability of intranasal diazepam in adults with epilepsy. Epilepsia 2014, 55, 1544-1550. [CrossRef]

66. Henney, H.R.; Sperling, M.R.; Rabinowicz, A.L.; Bream, G.; Carrazana, E.J. Assessment of pharmacokinetics and tolerability of intranasal diazepam relative to rectal gel in healthy adults. Epilepsy Res. 2014, 108, 1204-1211. [CrossRef] [PubMed] 
67. Kapoor, M.; Winter, T.; Lis, L.; Georg, G.I.; Siegel, R.A. Rapid Delivery of Diazepam from Supersaturated Solutions Prepared Using Prodrug/Enzyme Mixtures: Toward Intranasal Treatment of Seizure Emergencies. AAPS J. 2014, 16, 577-585. [CrossRef] [PubMed]

68. Inokuchi, R.; Ohashi-Fukuda, N.; Nakamura, K.; Wada, T.; Gunshin, M.; Kitsuta, Y.; Nakajima, S.; Yahagi, N. Comparison of intranasal and intravenous diazepam on status epilepticus in stroke patients: A retrospective cohort study. Med. Baltim. 2015, 94, e555. [CrossRef] [PubMed]

69. Sharma, D.; Sharma, R.K.; Sharma, N.; Gabrani, R.; Sharma, S.K.; Ali, J.; Dang, S. Nose-To-Brain Delivery of PLGA-Diazepam Nanoparticles. AAPS Pharmscitech 2015, 16, 1108-1121. [CrossRef] [PubMed]

70. Ramreddy, S.; Janapareddi, K. Brain targeting of chitosan-based diazepam mucoadhesive microemulsions via nasal route: Formulation optimization, characterization, pharmacokinetic and pharmacodynamic evaluation. Drug Dev. Ind. Pharm. 2019, 45, 147-158. [CrossRef]

71. Rautiola, D.; Maglalang, P.D.; Cheryala, N.; Nelson, K.M.; Georg, G.I.; Fine, J.M.; Svitak, A.L.; Faltesek, K.A.; Hanson, L.R.; Mishra, U.; et al. Intranasal Coadministration of a Diazepam Prodrug with a Converting Enzyme Results in Rapid Absorption of Diazepam in Rats. J. Pharmacol. Exp. Ther. 2019, 370, $796-805$. [CrossRef]

72. Hogan, R.; Sperling, M.; Klein, P.; Segal, E.; Carrazana, E. Pharmacokinetic Study of Valtoco ${ }^{\mathrm{TM}}$ (NRL-1; Diazepam Nasal Spray) in Patients with Epilepsy under Ictal and Inter-Ictal Conditions-Interim Report (P3.5-009); Neurology: Minneapolis, MN, USA, 2019; Volume 92, 46p.

73. Hogan, R.E.; Gidal, B.E.; Koplowitz, B.; Koplowitz, L.P.; Lowenthal, R.E.; Carrazana, E. Bioavailability and safety of diazepam intranasal solution compared to oral and rectal diazepam in healthy volunteers. Epilepsia 2020, 61, 455-464. [CrossRef]

74. Tarquinio, D.; Hogan, R.E.; Sperling, M.R.; Wheless, J.W.; Dlugos, D.; Miller, I.; Rabinowicz, A.L.; Carrazana, E. Safety and Tolerability of NRL-1, an Intranasal Formulation of Diazepam, in Subjects with Epilepsy in a Phase 1, Open-Label Study: Focus on Adverse Events Relevant to Clinicians and Patients (2044). Neurology 2020, 94, 2044.

75. Miller, I.; Wheless, J.W.; Hogan, R.E.; Dlugos, D.; Biton, V.; Cascino, G.D.; Sperling, M.R.; Liow, K.; Vazquez, B.; Ayala, R.; et al. Safety and Tolerability of NRL-1, an Intranasal Formulation of Diazepam, in Relationship to Usage Frequency in Subjects with Epilepsy: Interim Results From a Phase 3, Open-label, Repeat Dose Study (1992). Neurology 2020, 94, 1992.

76. Dean, P.; Santilli, N.; Wheless, J.W.; Vazquez, B.; Segal, E.B.; Miller, I.; Hogan, R.E.; Carrazana, E.; Rabinowicz, A.L. Low Rate of Medication Errors Supports the Ability of Patients and Caregivers to Administer NRL-1, an Intranasal Formulation of Diazepam: Interim Results from a Phase 3, Open-Label, Repeat Dose Study (1875). Neurology 2020, 94, 1875.

77. Acorda. Development of a Nasal Form of Diazepam Stopped. Epilepsy Found. 2016, 214, 161-165. Available online: https://www.epilepsy.com/article/2016/5/development-nasal-form-diazepam-stopped (accessed on 29 November 2020).

78. Neurelis, Inc. Neurelis Intranasal Diazepam Treatment for Epilepsy Granted Fast Track Designation by FDA; Neurelis, Inc.: San Diego, CA, USA, 2017.

Publisher's Note: MDPI stays neutral with regard to jurisdictional claims in published maps and institutional affiliations.

(C) 2020 by the authors. Licensee MDPI, Basel, Switzerland. This article is an open access article distributed under the terms and conditions of the Creative Commons Attribution (CC BY) license (http://creativecommons.org/licenses/by/4.0/). 